九州大学学術情報リポジトリ

Kyushu University Institutional Repository

\title{
A NEW SPECIES OF THE GENUS HALICTOPHAGUS FROM IRIOMOTE ISLAND, OKINAWA, JAPAN (STREPSIPTERA : HALICTOPHAGIDAE) (Studies on the Japanese Strepsiptera IV)
}

Hirashima, Yoshihiro

https://doi.org/10.5109/2373

出版情報: ESAKIA. 11，pp.59-61，1978-03-31. Entomological Laboratory，Faculty of Agriculture， Kyushu University

バージョン :

権利関係 : 


\title{
A NEW SPECIES OF THE GENUS HALICTOPHAGUS FROM IRIOMOTE ISLAND, OKINAWA, JAPAN (STREPSIPTERA : HALICTOPHAGIDAE)
}

(Studies on the Japanese Strepsiptera IV) ${ }^{1}$

\author{
Y OSHIHIRo Hirashima \\ Entomological Laboratory, Faculty of Agriculture \\ Kyushu University, Fukuoka 812, Japan \\ and \\ TEIJI KIFUNE \\ Department of Parasitology, School of Medicine \\ Fukuoka University, Fukuoka 814, Japan
}

\begin{abstract}
Halictophagus iriomotensis sp. n. (Strepsiptera : Halictophagidae) is described based on a single male specimen collected on Iriomote Island, Okinawa, Japan. This is the second species of the genus Halictophagus from Japan and the third species of the order from the Ryukyus.
\end{abstract}

Although more than 10 species of the strepsipterous insects have been discovered from Japan, only two species, Pseudoxenos iwatai Esaki, 1931, Stichotrema asahinai Hirashima et Kifune, 1974, are known from the Ryukyus. The former is parasitic on the vespid wasps and the latter is, very interestingly, associated with an orthopteran Mecopoda elongata.

This paper reports the third species of Strepsiptera from the Ryukyus which is a new species of Halictophagus collected on Iriomote Island

\section{Halictophagus iriomotensis $\mathrm{sp} . \mathrm{n}$.}

Male.

Size: Total length of body about $2 \mathrm{~mm}$, wing expanse (from base to the furthest lateral margin) about $2.1 \mathrm{~mm}$, head width $0.7 \mathrm{~mm}$.

color : Almost entirely black in dried condition.

Structure: Typical form of the genus ; head transversely elongated, frontal region entirely protruded; eyes spherical, slightly elongated, composed of about

1) Contribution from the Entomological Laboratory, Faculty of Agriculture, Kyushu University, Fukuoka (Ser. 3, No. 45). 
20 facets; antennae 7-segmented, 1st and 2nd segments short, 3rd to 6th segments short but each with a long flabellum, which is almost equal to 7 th segment in length; flabellum of 3rd segment slightly broader and stouter than those of other segments or 7 th segment itself.
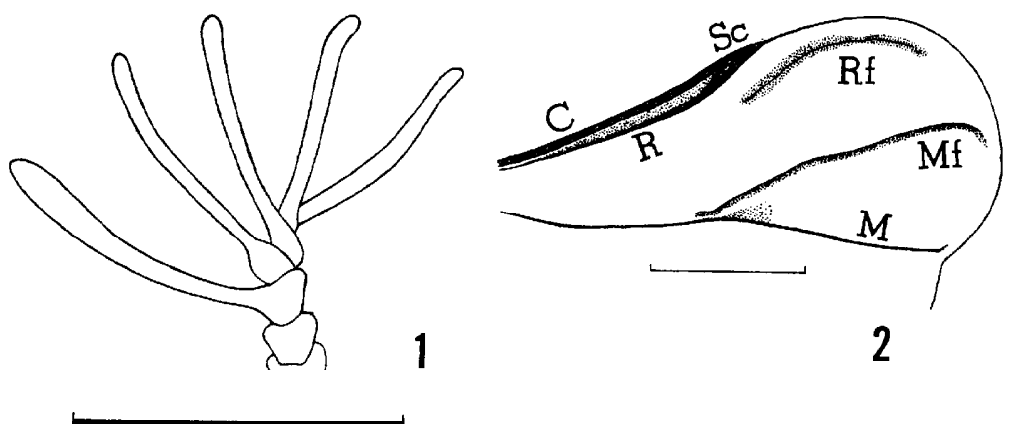

Figs. I-2. Halictophagus iriomotensis sp. n. 1: Left antenna. 2: Anterior part of right hindwing. Scale $: 0.5 \mathrm{~mm}$.

Hind wing with $\mathrm{C}, \mathrm{Sc}, \mathrm{R}, \mathrm{Rf}, \mathrm{Mf}, \mathrm{M}, \mathrm{Cu}, 1 \mathrm{~A}$, and $2 \mathrm{~A} ; \mathrm{C}, \mathrm{Sc}$, and $\mathrm{R}$ situated about basal two-thirds of anterior margin, $\mathrm{Rf}$ fragmental, conspicuously arcuate anteriorly and almost parallel to wing margin, originating a little posterior to end of $\mathrm{R}$ and ending near anterolateral angle of wing; $\mathrm{Mf}$ also fragmental, originating from median portion of $\mathrm{M}$ and almost reaching lateral wing margin obliquely, somewhat parallel to anterior wing margin, and the tip of it directed posteriorly; $M$ almost reaching wing margin and its tip shortly directed anteriorly; $\mathrm{Cu}$ and $1 \mathrm{~A}$ reaching posterolateral wing margin ; $2 \mathrm{~A}$ short and almost in contact with interior wing margin.

Thorax and abdomen as well as aedeagus are somewhat deformed because of the specimen being in dried condition, and no remarkable character is observed for this species.

\section{Female and triungulin.}

Unknown.

Type material : Holotype male (Type. No. 2087, Kyushu Univ.), in dry condition, Ohara, Iriomote Island, September 4, 1969 (M. Kinjo).

Type depository: The holotype is deposited in the collection of the Entomological Laboratory, Faculty of Agriculture, Kyushu University.

Remarks : The present new species resembles, in general structures, to Halictophagus fulmeki (Hofeneder, 1927) from Sumatra and H. membraciphaga (Subramanian, 1927) from South India, but differs from them by the venation of hind wing. $H$. orientalis (Esaki et Hashimoto, 1931) from Japan proper, is distinctive and easily recognizable by the structure of antennae and the venation. Judging from the size of body of $H$. iriomotensis sp. n., which is comparatively large in the genus, the host of it may be a certain large-sized Homoptera such as Deltocephalidae or Tettigellidae. 
A NEW SPECIES OF HALICTOPHAGUS FROM IRIOMOTE ISLAND

\section{Acknowledgments}

We are much indebted to Dr. S. Azuma and Mr. M. Kinjo, University of the Ryukyus, who kindly offered the interesting material. 